ENTREPRENEURSHIP AND SUSTAINABILITY ISSUES

ISSN 2345-0282 (online) http://jssidoi.org/jesi/

2020 Volume 7 Number 4 (June)

http://doi.org/10.9770/jesi.2020.7.4(49)

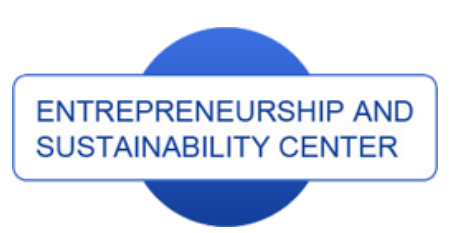

Publisher

http://jssidoi.org/esc/home

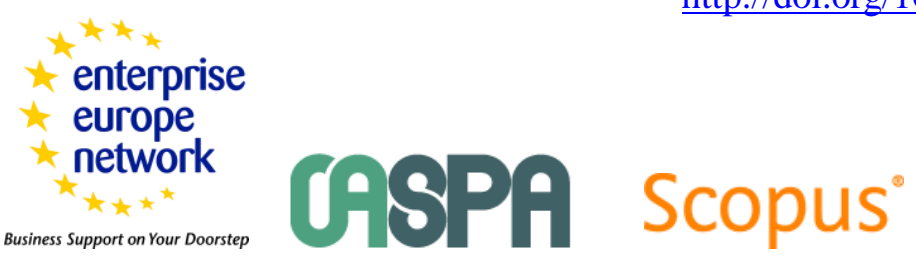

Business Support on Your Doorstep

1 Clarivate

Analytics

\title{
A HOLISTIC ASSESSMENT OF THE RISKS ENCOUNTERED BY FAST MOVING CONSUMER GOODS SMES IN SOUTH AFRICA
}

\author{
Oscar Chakabva ${ }^{1}$, Robertson K. Tengeh ${ }^{2 *}$, Jobo Dubihlela ${ }^{3}$ \\ ${ }^{1,2,3}$ Faculty of Business and Management Sciences, Cape Peninsula University of Technology, \\ South Africa \\ E-mails: ${ }^{1}$ chakabvao@gmail.com; ${ }^{2 *}$ tengehr@cput.ac.za; ${ }^{3}$ dubihlelaj@cput.ac.za
}

Received 11 October 2019; accepted 18 April 2020; published 30 June 2020

\begin{abstract}
Fast moving consumer goods (FMCG) small and medium-sized enterprises (SMEs) play an indispensable role in the emerging economies by selling products that are often classified as necessities. This paper argues that the traditional classification of risks into mainly operational, strategic, financial, and compliance risk, exposes FMCG SMEs to sustainability issues today. Focusing on sustainability and the associated factors, this paper seeks to offer a broader perspective on the risks that are crucial to the survival of FMCG SMEs in a fast-paced changing environment. The empirical investigation relied on the mixed research methods with the survey questionnaire and personal interviews as tools of interest. Two expert interviews were held to complement the quantitative data that was collected from 289 respondents. The research findings highlight the necessity for FMCG SMEs to look beyond the traditional risk types by incorporating social, economic and environmental risks, which are essential elements of the sustainability framework today. By combining these three components of sustainability into risk assessment, the paper seeks to introduce a more holistic view of risk sources that include evolving risk areas that are of growing importance in a rapidly changing global environment.
\end{abstract}

Keywords: risks, business survival, sustainability, traditional view, expanded view, Fast moving consumer goods (FMCG), SMEs, South Africa.

Reference to this paper should be made as follows: Chakabva, O., Tengeh, R.K., Dubihlela, J. 2020. A holistic assessment of the risks encountered by fast moving consumer goods SMEs in South Africa. Entrepreneurship and Sustainability Issues, 7(4), 3321-3338. http://doi.org/10.9770/jesi.2020.7.4(49)

JEL Classifications: M4, M10, M14, M42

\section{Introduction and background}

The fast-moving consumer goods (FMCG) industry, which caters for products that can be classified as necessities is regarded as one of the largest worldwide (KPMG, 2014). These necessities consist of a wide range of products, with some of the most significant categories being food, beverages, beauty products, toiletries, health care products and home care products (Stahel \& Clift, 2015). Because FMCGs products are usually similar within 


\section{ENTREPRENEURSHIP AND SUSTAINABILITY ISSUES}

ISSN 2345-0282 (online) http://jssidoi.org/jesi/

2020 Volume 7 Number 4 (June)

http://doi.org/10.9770/jesi.2020.7.4(49)

categories, FMCG SMEs have to compete on price (KPMG, 2014). Of course, fierce competition squeezes profit margins to the lowest levels, and the consequence is that the least efficient FMCG SMEs are pushed out of business (Hubner, Kuhn \& Sternbeck 2013). This is further aggravated by the fact that FMCGs are sold quickly and at a low-profit margin (Vaishnani, 2011).

Customarily organisations are tempted to align challenges to survival to strategic, operations, reporting and compliance issues (COSO, 2004). While this has been the practice, the fact that companies operate in a continually evolving environment challenges this paradigm and more so in the context of FMCGs. Perhaps this is why proactive organisations consider risk management as an ongoing process that seeks to identify risk exposures, measure their impact and apply the best methods of handling risk.

Today, the sources of risks in FMCG SMEs can no longer be confined to the traditional sources but rather seen through the sustainability lens - economic, social and environmental areas. For example, the World Economic Forum (WEF) Global Risks Report (2019) notes that in 2019, three of the top global risks in terms of likelihood and impact are from the components of sustainability. This is a significant shift from ten years ago when traditional risks like financial risks comprised the bulk of top global risks in terms of likelihood and impact (Irwin \& Kennedy, 2017). In support, components of sustainability, environmental, economic and social are increasingly shaping trends in the FMCG industry in terms of risk sources (Calton, 2001; Dietsche 2009; EMF, 2012; Schlierer et al., 2012; Koor, 2018; WEF, 2019; Daniel, 2019).

From the discussion above, it is clear that risks in FMCG SMEs are no longer confined to traditional sources, but are now expanding through the sustainability lens - social, economic and environmental areas. To our knowledge, there is currently no holistic risk management model that explicitly addresses the social, economic and environmental components of sustainability. The traditional risk management approaches, including Enterprise Risk Management (ERM), are inherently internally focused, as they only look at reporting, operational, compliance, and strategic factors. To contribute to filling this gap, this paper offers a broader perspective on risks that are crucial to the survival of FMCG SMEs. In this case, the expanded view of risks includes social, economic and environmental considerations. By incorporating these three components of sustainability into risk assessment, the paper seeks to introduce a more holistic view of risk sources that include evolving risk areas that are of growing importance in a rapidly changing global environment.

\section{Literature review}

This section of the paper explores the traditional categories of risks and an expanded view of risk categories.

\subsection{Traditional categories of risks}

Kaplan and Mikes (2012) note that all businesses (regardless of size and industry) encounter some form of risks in their day-to-day operations. Traditionally, these risks are split into five broad categories: operational risks, strategic risks, financial risks, compliance risks, and reporting risks (Deloitte, 2013; Godbole, 2012; Horcher, 2011; Coyle, 2004; Chehabeddine, Tvaronavičienè, 2020).

\subsubsection{Operational risks}

The Basel Committee on Banking Supervision (2001) suggests that operational risks are linked to failures in people, systems, policies and procedures of a business. For this reason, operational risk is defined as the probability of a loss happening due to human errors, fraud and failed internal controls (Basel Committee on Banking Supervision, 2011). Typical examples of operational risks include theft, fraud, system failures, human errors, and product or service failure, to mention but a few (Risk Management Association, 2017; Ayandibu \& Houghton, 2017; Goldberg \& Palladini, 2010; Ogbor, 2009). Operational risks are inherent in daily business activities (Hussain \& Shafi, 2014), and if not adequately dealt with, they may lead to substantial loss of income. 


\section{ENTREPRENEURSHIP AND SUSTAINABILITY ISSUES}

ISSN 2345-0282 (online) http://jssidoi.org/jesi/

2020 Volume 7 Number 4 (June)

http://doi.org/10.9770/jesi.2020.7.4(49)

For SMEs, operational risks like human errors, fraud and failure to recognise a shift in consumer tastes and preferences are the most prominent (Ismail, Othman, Yousop \& Ahmad, 2016). Concurring, Pradana and Bandula (2012) concede that operational risk is one of the most significant risks threatening the survival of SMEs today. Yusuf and Dansu (2013) pointed out that the threat to survival is complicated by the fact that the managerial decision-making in SMEs resides with the owner, who in most cases lacks the necessary managerial skills and qualities to manage the operations of the business successfully. Adhering to policies, procedures and internal controls is critical in preventing any undesirable outcome (CGAP, 2009; Bure \& Tengeh, 2019).

\subsubsection{Strategic risks}

Strategic risk refers to threats which materially affect the ability of the business to survive and grow (Allan \& Beer, 2006). According to the United Nations Educational, Scientific and Cultural Organization (UNESCO) (2010) such threats arise from: (1) Ambiguous business objectives; (2) Failure to identify threats and opportunities inside and outside the business; (3) Failure to strategically position the company in the international market; (4) Poor governance; and (5) Lack of strategic planning. As noted by Goldberg and Palladini (2010) and the Association of Chartered Certified Accountants (2015), strategic risks include, but is not limited to competition, lousy reputation, governance risk, and shift in consumer tastes and preferences. Such risks influence the achievement of strategic objectives (business's vision and mission) (Taylor, 2012); and the overall performance of the company (Mohammed \& Sykes, 2012). As a result, if not adequately dealt with, strategic risks may put the business's continued existence at stake (Tonello, 2012).

Concerning SMEs, authors such as Pradana and Bandula (2012); Ismail, Othman, Yousop and Ahmad (2016) concede that strategic risks which come from mainly planning, business decisions and changes in the business environment are considerably higher compared to the operational and financial risks. These authors believe that the pursuit of a failed business plan, poor business decisions and changes in the business environment constitute significant strategic risks that impact on the SMEs' profits. A potential explanation for this finding might be that of Watt (2007) who found that SME entrepreneurs lack the knowledge of how the business must be run and also have poor leadership styles. It is therefore likely that these entrepreneurs do not clearly define policies and procedures, and also fail to identify threats and opportunities inside and outside the business, which maximises the chances of strategic risk occurrence including governance risk and reputation risk.

\subsubsection{Financial risks}

According to Coyle (2004), financial risk is a broad term that is used to refer to multiple types of risks relating to credit transactions, liquidity and loans. Previous research by Horcher (2011) has established that the typical hazards that fall within the financial risk category include customer defaults, cash theft, and cash shortage. To Aureli and Salvatori (2013), financial risk is the most critical risks that SMEs face with cash flow risk, credit risk and commodity risk being typical examples in this category. These risk types are known to have a negative and significant influence on the revenue and profitability of SMEs (Nyakang'o \& Kalio, 2013). Limited use of funds and financial planning, which result in the accrual of financial risks is a plausible cause of financial risk (Zhao \& Zeng, 2014).

\subsubsection{Compliance risks}

Compliance risks are threats associated with adherence to industry laws and regulations, internal policies and procedures (Sales, 2014). These risks are closely interrelated with the operational loss, legal sanctions and reputation loss which often result from failure to act on laws, regulations and prescribed best practices (Brockett \& Rezaee, 2012). Some common forms of compliance risks that may impede FMCG SMEs include violation of Health and safety laws and non-adherence to applicable rules and regulations which govern the operations of the business (Johnson \& Johnson, 2013). SBP Alert (2013) identified the compliance burden as a significant setback currently facing South African SMEs. In support, Viviers (2004) indicates that the cost of compliance with legislation is high and is considered to be a significant threat to the South African SME industry. 


\section{ENTREPRENEURSHIP AND SUSTAINABILITY ISSUES}

ISSN 2345-0282 (online) http://jssidoi.org/jesi/

2020 Volume 7 Number 4 (June)

http://doi.org/10.9770/jesi.2020.7.4(49)

\subsubsection{Reporting risks}

According to the Center for Audit Quality (2012) reporting risks are associated with gathering, processing and reporting of information. This information could be financial or non-financial (Von Rossing, 2007). As such, reporting risks influence the reliability and integrity of financial or non-financial information which is reported to the internal and external stakeholders (Wurzler, 2013). Some common examples of reporting risks that may affect FMCG SMEs include the gathering of incomplete information, lack of access to information, information loss through unauthorized users, and gathering incorrect information from the market such as the wrong discovery of the product on demand. Singh, Chakraborty, Roy, and Tripathi (2020) decry the dearth of reporting that occurs in SMEs and the high dependence of narration instead of quantifiable data.

\subsection{Expanded view of risk categories}

An expanded view of risks looks at emerging risks from the three critical components of sustainability, which include economic, social and environmental factors.

\subsubsection{Economic risks}

Van Eeden, Viviers and Venter (2003) revealed that economic risks arise from economic factors like inflation, interest rates and foreign exchange rates. Hence, paying little or no attention to economic factors during risk assessments may pose multiple risks to FMCG SMEs during an economic meltdown. For instance, inflation poses risks like an unexpected increase in input costs (electricity, water, fuel, raw material, etc.), which subsequently reduces FMCG SME's profits. Beyond this, inflation erodes the disposable income of FMCG customers. In turn, this makes FMCG customers more price-conscious, resulting in a decline in sales and profits. Apart from inflation, unstable interest rates result in an unexpected increase in expenses which again reduces the earnings of the FMCG SMEs, particularly those that rely on debt capital. Moreover, fluctuations in foreign exchange rates also pose risks to FMCG SMEs.

\subsubsection{Social risks}

Calton (2001) suggests that social risks arise from the relationship between the business and various stakeholders such as customers and suppliers. For instance, any business without a skilled public relations person or a competent customer service representative to address customer complaints creates an opportunity for customer outrage (Sheehan, 2013). This, in turn, is likely to lead to customers not returning to buy from the business, failure to attract new customers and loss of revenue and profits (Surridge \& Gillespie, 2017). It is, therefore, imperative for every SME to implement effective customer relationship management (CRM) to ensure that customers are served in the best possible way. Concerning suppliers, delaying payments to suppliers beyond the agreed credit period tarnishes a good relationship with suppliers (Enow \& Kamala, 2016), which leads to the loss of key suppliers. So, bringing on board suitable suppliers and maintaining strong relations with them can be an indispensable tool in the quest for FMCG SMEs success and expansion (Banerjee, Dasgupta \& Kim, 2008).

\subsubsection{Environment risks}

Environmental aspects relate to preserving natural resources and the ecosystem (Ikediashi, Ogunlana \& Ujene, 2014). For FCMG SMEs, issues like energy, water crisis and food packaging can have tangible effects on their operations and production, and subsequent commercial performance.

\subsubsection{Energy}

Energy is a prime input for FMCG SMEs, being used in their daily activities like cooking, air conditioning and refrigeration of their products. The Green Restaurant Association (2005) revealed that the FMCG industry, mainly the restaurant sector is the number one electricity consumer in the entire retail industry. If not correctly managed, energy use may result in excessive energy consumption which certainly poses risks such as an increase in municipal costs and a downward spiral for profits. Thus, operating costs often increase as a result of excessive 


\section{ENTREPRENEURSHIP AND SUSTAINABILITY ISSUES}

ISSN 2345-0282 (online) http://jssidoi.org/jesi/

2020 Volume 7 Number 4 (June)

http://doi.org/10.9770/jesi.2020.7.4(49)

energy consumption, but market price remains stable, leading to decreased profits. Therefore, FMCG SMEs should act to reduce their overall energy consumption through efficiency and waste reduction or switch to renewable sources.

\subsubsection{Water}

The operating activities of FMCG SMEs, especially restaurants, are heavily reliant on water and use about 5800 gallons per day of water (Tampa Water Department, 2010). Therefore, the problems of too little water can affect the direct operations of FMCG SMEs or cause supply chain disruption. With Cape Town presently being flaunted around the world as possibly the first major city to run out of the water (Koor, 2018), FMCG SMEs must take a closer look at their water conservation techniques to ensure that they consider the risks posed to them by the water crisis.

\subsubsection{Packaging}

The primary use of packaging has always been to preserve the product. Nowadays, packaging has become an important marketing strategy that is used within the FMCG retail industry to lure attention, describe the product and subsequently achieve higher sales revenue (Coles \& Kirwan, 2011). However, the packaging is associated with multiple environmental issues. Thus, it is often mismanaged when the product has reached the final phase of its life cycle. The U.S. Environmental Protection Agency (EPA) (2013) has revealed that packaging generated over 75 million tonnes of US municipal waste. Nearly $48.5 \%$ of this waste could not be recovered and ended up in excavated pits. Therefore, FMCG SMEs should pursue sustainable packaging techniques failure of which may pose reputational risks or loss of customers. For example, these days many brands are identifiable through their packaging and customers are now prepared to substitute or boycott certain brands that behave irresponsibly concerning the environmental impact of packaging (Forum for the Future, 2014).

\section{Research Methods}

A mixed research method that necessitated the use of a questionnaire and an interview guide as tools within the quantitative and qualitative research paradigms was adopted for data collection. The qualitative approach served to validate the quantitive one.

\subsection{Population and sampling}

The population of interest for this study comprised of all of the FMCG SMEs that operated within the Cape Metropolitan area of South Africa at the time of the study. The sampling frame was limited to FMCG SMEs operating in the retail industry and particularly those operating within the Cape Metropolitan area of South Africa. FMCG SMEs were chosen as they are perceived to be the most critical enterprises in the SME sector because of the nature of their products (necessities and perishables) (Singh, 2014).

To ensure that only participants with sufficient and relevant work experience in the field of risk management were selected during the sampling process, the research population was limited to managers and owners of FMCG SMEs within the Cape Metropolitan area. Managers and owners were chosen as these people are considered to be the decision-makers in their businesses. As such, they are likely to be familiar with their risk management practices.

In the absence of a comprehensive record of all FMCG SMEs within the Cape Metropolitan area, the purposive sampling technique was utilised select the 289 FMCG SMEs that took part in the quantitative component of the study. A questionnaire was used to collect the data. The following criterion was adhered to ensure that the relevant information was collected:

- The businesses had to employ a minimum of 5 people and a maximum of 200 people in terms of the South African Small Business Amendment Act (No. 26 of 2003). 


\section{ENTREPRENEURSHIP AND SUSTAINABILITY ISSUES}

ISSN 2345-0282 (online) http://jssidoi.org/jesi/

2020 Volume 7 Number 4 (June)

http://doi.org/10.9770/jesi.2020.7.4(49)

- All respondents had to be owners or managers of their businesses.

- All research participants must have been responsible for sustainability and risk management in their businesses for a minimum of 3 years, to ensure that the participants have gained experience in the business and know the policies in place.

For the qualitative part of the study, LinkedIn was used as a method for recruiting participants for personal interviews. LinkedIn is the leading platform for professional networking, which makes it the optimum choice for this study since the study seeks to reach people in a particular profession - risk experts. In the first step, one of the authors of this paper logged onto LinkedIn with his account and searched for "risk consultants in Cape Town". This approach relied on individuals self-identifying themselves as risk consultants or something similar. In this case, LinkedIn proved fruitful as it returned 5174 results, which was narrowed down to 30 possible participants. A list of 30 potential participants was deemed adequate since the study targeted only 2 participants. To come up with the 30 potential participants, we first vetted the credentials by going through the LinkedIn profiles, only those that we thought would best enhance the study were selected. For each chosen candidate, we noted his or her name, risk experience, location and any other relevant information listed in the profile. This information is already in the public domain and thus, we have implied consent. Each potential participant was then sent a personalised recruitment message explaining the study and how we identified him or her as a possible participant.

Out of the 30 invitations sent out, 27 responses were received, and 3 did not respond at all. Of the 27 responses received, 7 declined to take part in the study for a variety of reasons. For instance, 1 indicated that he was overseas on a conference, 5 indicated that they were not in Cape Town at that time without giving any further information. We then applied the criteria of availability and willingness to participate, resulting in a sampling frame of 14 risk experts. The next step was to draw a sample of 2 interviewees from the sampling frame. To achieve this, we thought of using the order in which the responses to invitations were received. As such, the first two positive respondents were selected.

\subsection{Data analysis}

Of the 320 questionnaires completed, only 289 were usable. The numeric data collected from the respondents was analysed using SAS software, following three intermediate steps: (1) data preparation; (2) descriptive statistics; and (3) inferential statistics. In the end, the numeric data was summarised numerically and in a table format. These summaries were then comprehensively discussed in the context of this study. To validate the numeric data, non-numeric data collected from participants through interviews was analysed using qualitative content analysis method, following three distinct analytical procedures. In the first step, a list of key themes was generated, and the themes were organised into categories that were identified as critical findings. Then, the nonnumeric data was analysed in order to classify it into these categories. Finally, the categories (key results) were analysed to establish commonalities amongst the participants' responses, and conclusions were drawn from the data.

\section{Results and discussion}

\subsection{Themes arising from the personal interviews}

The interview questions were in the form of both general and in-depth questions. The general question provided information on the background of the participants. Conversely, detailed questions attempted to understand the participants' perspectives on the variables relating to this study. The business risk experts who took part in this study were labelled as Participant - BRE1 and Participant - BRE2. 


\subsubsection{General question}

In an attempt to validate the information obtained from LinkedIn and ensure that the business risk experts are currently involved in the field of risk management, and have been in this field for at least 3 years as stipulated in the delineation criteria, a general question was formulated to capture such information. Based on the responses from the business risk experts regarding their experience and current involvement in the field of risk management, the following findings were noted (Table 1):

Table 1. Participants' experience and ongoing involvement in the field of risk management

\begin{tabular}{|l|l|}
\hline Theme question: Tell me about your experience and current involvement in the field of risk management? \\
\hline $\begin{array}{l}\text { Theme } \\
\begin{array}{l}\text { Current involvement } \\
\text { management }\end{array}\end{array}$ & $\begin{array}{l}\text { Findings } \\
\text { manth Participant - BRE1 and Participant - BRE2 are currently working in the field of risk } \\
\text { mant as a senior risk officer and risk management consultant, respectively. }\end{array}$ \\
\hline $\begin{array}{l}\text { Risk management } \\
\text { experience }\end{array}$ & Both participants have been in the field of risk management for at least 3 years. \\
\hline
\end{tabular}

Source: authors

\subsubsection{In-depth questions}

To validate the results of the quantitative survey data, two in-depth interview questions were undertaken to capture the relevant information.

\subsubsection{Traditional view: Major business risks that affect FMCG SMEs' performance}

Based on the responses from the business risk experts regarding the significant risks that affect the performance of FMCG SMEs from a traditional perspective, the following findings were observed (Table 2):

Table 2. Major business risks that affect FMCG SMEs' performance

Theme question: Taking into account your experience and knowledge in managing risks: in brief, what would you say are the significant risks affecting the performance of FMCG SMEs in South Africa?

\begin{tabular}{|l|l|}
\hline Theme & Findings \\
\hline Major risks & $\begin{array}{l}\text { The business risk experts who participated in this study generally recognise the loss of competitive } \\
\text { advantage, cash flow deficit, compliance risks, cyber risks, employee theft, spoiling of refrigerated } \\
\text { products due to load-shedding and damage to appliances due to a sudden power surge as the significant } \\
\text { risks that affect the performance of FMCG SMEs. }\end{array}$ \\
\hline
\end{tabular}
Source: authors

\subsubsection{An expanded view: Potential risks posed to FMCG SMEs by components of sustainability} Based on the responses from the business risk experts regarding the risks posed to FMCG SMEs by elements of sustainability, the following findings were pointed out (Table 3):

Table 3. Identifying potential risks posed to SMEs by pillars of sustainability

\begin{tabular}{|c|c|}
\hline \multicolumn{2}{|c|}{$\begin{array}{l}\text { Theme question: In this study, business sustainability is defined as the management and coordination of environmental, social and } \\
\text { economic factors to ensure a responsible, moral and ongoing success. About this definition, what do you think are the risks, if any, } \\
\text { posed to FMCG SMEs by sustainability factors? }\end{array}$} \\
\hline Theme & Findings \\
\hline $\begin{array}{l}\text { Risks posed by } \\
\text { sustainability } \\
\text { factors }\end{array}$ & $\begin{array}{l}\text { In both interviews, it was noted that the risks that the sustainability factors pose to FMCG SMEs include: } \\
\text { higher costs for energy, water and other resources, extreme water restrictions due to climate changes, } \\
\text { significant loss due to economic circumstances like inflation, public outcry and damage to reputation. }\end{array}$ \\
\hline
\end{tabular}




\subsection{Results of the quantitative survey}

The survey questionnaire constituted the main source of primary data in this study even though personal interviews were also used. Table 4 to 10 show the descriptive statistics for all the questions/statements in the survey questionnaire, with the frequencies in each category and the percentage out of the total number of the specific questions completed. The descriptive statistics are based on the full sample. In instances where there were no answers given, it was shown as unknown in the descriptive statistics (Table 4).

\subsubsection{Descriptive statistics for demographic variables}

Table 4. Descriptive statistics for all the variables in the survey

\begin{tabular}{|c|c|c|c|}
\hline Variables & Categories & Frequency & $\begin{array}{l}\text { Percentage out of } \\
\text { total }\end{array}$ \\
\hline \multirow[t]{9}{*}{ business operates as ...? } & Caterer & 28 & $9.7 \%$ \\
\hline & Retail shop & 73 & $25.3 \%$ \\
\hline & Restaurant & 45 & $15.6 \%$ \\
\hline & Wholesale shop & 26 & $9.0 \%$ \\
\hline & Café & 25 & $8.6 \%$ \\
\hline & Pharmacy & 22 & $7.6 \%$ \\
\hline & Liquor store & 17 & $5.9 \%$ \\
\hline & Convenient shop & 41 & $14.2 \%$ \\
\hline & Other & 12 & $4.2 \%$ \\
\hline
\end{tabular}

Source: authors

According to Table 4, the respondents are not equally distributed in terms of the businesses that they were operating at the time of the survey. It seems that the difference lies in the fact that there are more respondents in the retail $(25.3 \%)$, restaurant $(15.6 \%)$ and convenient $(14.2 \%)$ businesses than they are in the other types of businesses. The respondents who selected "other" businesses that they are operating as, indicated that these businesses are butcheries, chicken and chips shops, fast foods outlets, fruit and vegetable shops, hair salon shops. Very few of the surveyed SMEs were into buying and selling products which are subject to strict regulations like alcohol $(5.9 \%)$ and medical products $(7.6 \%)$. As such, the probable characteristics of the SMEs noted in this study concerning the type of business are easy of entry, less regulation and less capital required to set-up and run them (Table 5).

Table 5. Descriptive statistics for all the variables in the survey

\begin{tabular}{|l|c|c|c|}
\hline Variables & Categories & $\begin{array}{c}\text { Frequency } \\
\text { Percentage out of } \\
\text { total }\end{array}$ \\
\hline How long have you been in your current position? & $0-5$ years & 125 & $43.2 \%$ \\
\cline { 2 - 4 } & $6-10$ years & 100 & $34.6 \%$ \\
& $11-15$ years & 35 & $12.1 \%$ \\
\cline { 2 - 4 } & $16-20$ years & 28 & $9.7 \%$ \\
\cline { 2 - 4 } & More than 20 years & 1 & $0.0 \%$ \\
\cline { 2 - 4 } & Unknown & 1 & $0.4 \%$ \\
\hline
\end{tabular}

Source: authors

According to Table 5, the respondents are not equally distributed with regards to the period that they have been in their current positions. Thus, $43.4 \%$ of the respondents indicated that they have been in their positions for $0-5$ years, $34.7 \%$ have been in their positions for 6-10 years, $12.2 \%$ have been in their positions for 11-15 years, and 9.7\% have been in their positions for 16-20 years. It should be noted that this study assumed that the number of years of experience of the respondents could influence their responses. As a result, only questionnaires that were 
completed by respondents who have three years of experience or above were included in the survey. This, therefore, means that $43.4 \%$ for the 0-5 year group represents respondents with 3-5 years of experience.

\subsubsection{Traditional view: Identifying the major business risks that affect FMCG SMEs' performance}

Table 6. Descriptive statistics for financial risk

\begin{tabular}{|c|c|c|c|}
\hline Variables & Categories & Frequency & $\begin{array}{c}\text { Percentage out of } \\
\text { total }\end{array}$ \\
\hline \multirow[t]{5}{*}{ Customer defaults } & No effects & 171 & $59.2 \%$ \\
\hline & Minor effects & 94 & $32.5 \%$ \\
\hline & Neutral & 4 & $1.4 \%$ \\
\hline & Moderate effects & 12 & $4.2 \%$ \\
\hline & Major effects & 8 & $2.8 \%$ \\
\hline \multirow[t]{5}{*}{ Theft of cash by employees } & No effects & 50 & $17.3 \%$ \\
\hline & Minor effects & 33 & $11.4 \%$ \\
\hline & Neutral & 5 & $1.7 \%$ \\
\hline & Moderate effects & 29 & $10.0 \%$ \\
\hline & Major effects & 172 & $59.5 \%$ \\
\hline \multirow[t]{5}{*}{ Cash shortage } & No effects & 42 & $14.5 \%$ \\
\hline & Minor effects & 48 & $16.6 \%$ \\
\hline & Neutral & 2 & $0.7 \%$ \\
\hline & Moderate effects & 38 & $13.2 \%$ \\
\hline & Major effects & 159 & $55.0 \%$ \\
\hline \multirow[t]{6}{*}{ Unexpected increase in finance costs } & No effects & 135 & $46.7 \%$ \\
\hline & Minor effects & 71 & $24.6 \%$ \\
\hline & Neutral & 7 & $2.4 \%$ \\
\hline & Moderate effects & 26 & $9.0 \%$ \\
\hline & Major effects & 49 & $17.0 \%$ \\
\hline & Unknown & 1 & $0.4 \%$ \\
\hline
\end{tabular}

Source: authors

The results of the survey questionnaire on financial risks indicate that the risk of customer defaults is relatively low in FMCG SMEs (Table 6). A possible explanation is that most of the FMCG SMEs operate on a cash and carry basis. Furthermore, the survey questionnaire results revealed that theft of cash by employees and cash shortages are the most critical financial risks faced by FMCG SMEs.

This is in congruence with Zhao and Zeng (2014) who assert that SMEs lack adequate internal controls and proper financial planning, which culminate in the accumulation of financial risks. The results of the personal interviews did not show any parallel or new data regarding financial risks (Table 7). 


\section{ENTREPRENEURSHIP AND SUSTAINABILITY ISSUES}

ISSN 2345-0282 (online) http://jssidoi.org/jesi/

2020 Volume 7 Number 4 (June)

http://doi.org/10.9770/jesi.2020.7.4(49)

Table 7. Descriptive statistics for operational risks

\begin{tabular}{|c|c|c|c|}
\hline Variables & Categories & Frequency & $\begin{array}{c}\text { Percentage out of } \\
\text { total }\end{array}$ \\
\hline \multirow[t]{5}{*}{ Product failure } & No effects & 51 & $17.6 \%$ \\
\hline & Minor effects & 31 & $10.7 \%$ \\
\hline & Neutral & 2 & $0.7 \%$ \\
\hline & Moderate effects & 85 & $29.4 \%$ \\
\hline & Major effects & 120 & $41.5 \%$ \\
\hline \multirow[t]{5}{*}{ Theft of trading stocks } & No effects & 53 & $18.3 \%$ \\
\hline & Minor effects & 33 & $11.4 \%$ \\
\hline & Neutral & 3 & $1.0 \%$ \\
\hline & Moderate effects & 26 & $9.0 \%$ \\
\hline & Major effects & 174 & $60.2 \%$ \\
\hline \multirow[t]{5}{*}{ Employee errors - overpaying/underpaying customers } & No effects & 57 & $19.7 \%$ \\
\hline & Minor effects & 27 & $9.3 \%$ \\
\hline & Neutral & 4 & $1.4 \%$ \\
\hline & Moderate effects & 22 & $7.6 \%$ \\
\hline & Major effects & 179 & $61.9 \%$ \\
\hline \multirow[t]{5}{*}{ Systems and device failures } & No effects & 59 & $20.4 \%$ \\
\hline & Minor effects & 116 & $40.1 \%$ \\
\hline & Neutral & 4 & $1.4 \%$ \\
\hline & Moderate effects & 49 & $17.0 \%$ \\
\hline & Major effects & 61 & $21.1 \%$ \\
\hline
\end{tabular}

Source: authors

The survey questionnaire results on operational risks disclosed that the operational risk faced by FMCG SMEs is high in the area of employee errors, theft of trading stock and product failure. Likewise, the personal interviews conducted with the risk experts conceded with these findings. Accordingly, below is what one of the business risk experts interviewed had to say:

"....load-shedding which has now been raised to Stage 4 is also posing significant risks to the retail industry especially to small retailers without backup power, for example, the spoiling of refrigerated products, damage to appliances as a result of sudden power surge et cetera..." (Participant - BRE1).

The findings on operational risks are in congruence with the results of Yusuf and Dansu (2013) which revealed that managerial decisions in SMEs are made by the owner, who in most cases lacks necessary managerial skills and qualities to manage the operations of the business successfully (Table 8). 
ENTREPRENEURSHIP AND SUSTAINABILITY ISSUES

ISSN 2345-0282 (online) http://jssidoi.org/jesi/

2020 Volume 7 Number 4 (June)

http://doi.org/10.9770/jesi.2020.7.4(49)

Table 8. Descriptive statistics for strategic risks

\begin{tabular}{|c|c|c|c|}
\hline Variables & Categories & Frequency & $\begin{array}{c}\text { Percentage out of } \\
\text { total }\end{array}$ \\
\hline \multirow[t]{5}{*}{ Damage to reputation } & No effects & 53 & $18.3 \%$ \\
\hline & Minor effects & 28 & $9.7 \%$ \\
\hline & Neutral & 3 & $1.0 \%$ \\
\hline & Moderate effects & 45 & $15.6 \%$ \\
\hline & Major effects & 160 & $55.4 \%$ \\
\hline \multirow[t]{5}{*}{ Employees' disputes } & No effects & 55 & $19.0 \%$ \\
\hline & Minor effects & 36 & $12.5 \%$ \\
\hline & Neutral & 0 & $0.0 \%$ \\
\hline & Moderate effects & 43 & $14.9 \%$ \\
\hline & Major effects & 155 & $53.6 \%$ \\
\hline \multirow[t]{5}{*}{ Administrative errors } & No effects & 66 & $22.8 \%$ \\
\hline & Minor effects & 49 & $17.0 \%$ \\
\hline & Neutral & 0 & $0.0 \%$ \\
\hline & Moderate effects & 20 & $6.9 \%$ \\
\hline & Major effects & 154 & $53.3 \%$ \\
\hline
\end{tabular}

Source: authors

Table 8, suggests that strategic risk in FMCG SMEs is high in the areas of reputation, employees' disputes and administrative errors. This is in line with Watt (2007) who found that SME entrepreneurs often lack the knowledge of how the business must be run and, they have poor leadership styles. The personal interviews did not reveal any contradicting results but just added loss of competitive advantage as another strategic risk bedevilling SMEs. Accordingly, one of the risk experts made the following comment:

"They face many risks, firstly, there are so many big players in the retail industry and attaining competitive advantage is one of the most challenging issues facing small retailers... " Participant - BRE1).

Table 9. Descriptive statistics for compliance risks

\begin{tabular}{|c|c|c|c|}
\hline Variables & Categories & Frequency & $\begin{array}{l}\text { Percentage } \\
\text { out of total }\end{array}$ \\
\hline \multirow[t]{5}{*}{ Heavy fines } & No effects & 0 & $0.0 \%$ \\
\hline & Minor effects & 38 & $13.2 \%$ \\
\hline & Neutral & 100 & $34.6 \%$ \\
\hline & Moderate effects & 83 & $28.7 \%$ \\
\hline & Major effects & 68 & $23.5 \%$ \\
\hline \multirow[t]{5}{*}{ Withdrawal/suspension of trade license } & No effects & 0 & $0.0 \%$ \\
\hline & Minor effects & 39 & $13.5 \%$ \\
\hline & Neutral & 94 & $32.5 \%$ \\
\hline & Moderate effects & 87 & $30.1 \%$ \\
\hline & Major effects & 69 & $23.9 \%$ \\
\hline
\end{tabular}

Source: authors

The survey questionnaire results on compliance risks suggest that FMCG SMEs are not faced with high compliance risk (Table 9). On the contrary, some researchers have different opinions on compliance risks. Thus, the SBP Alert (2013) and Viviers (2004) indicate that the cost of adhering to legislation is relatively high and is regarded as one of the most important risks faced by the South African SME industry. In line with prior research, the risk experts interviewed made the following comments: 
“.... Lastly, compliance with laws and regulations is a greater hindrance on small and medium retailers than on large retailers; it hinders their formation and growth". (Participant - BRE1).

"...Apart from this, retail SMEs often find regulation challenging mainly because they lack the capacity to deal with regulation requirements making compliance difficult to achieve for them..." (Participant - BRE2).

The aforementioned findings send mixed opinions relating to whether the survey participants who have indicated that compliance is not a major risk area actually meant it or whether it's a matter of lack of knowledge.

\subsubsection{An expanded view: Potential risks posed to FMCG SMEs by components of sustainability}

Table 10. Risk posed to my business by components of sustainability

\begin{tabular}{|c|c|c|c|}
\hline Variables & Categories & Frequency & $\begin{array}{l}\text { Percentage out of } \\
\text { total }\end{array}$ \\
\hline \multicolumn{4}{|c|}{ Social } \\
\hline \multirow[t]{5}{*}{ Loss of customers } & Strongly disagree & 14 & $4.8 \%$ \\
\hline & Disagree & 18 & $6.2 \%$ \\
\hline & Undecided & 18 & $6.2 \%$ \\
\hline & Agree & 25 & $8.6 \%$ \\
\hline & Strongly agree & 214 & $74.0 \%$ \\
\hline \multirow[t]{5}{*}{ Loss of key suppliers } & Strongly disagree & 20 & $6.9 \%$ \\
\hline & Disagree & 25 & $8.6 \%$ \\
\hline & Undecided & 26 & $9.0 \%$ \\
\hline & Agree & 52 & $18.0 \%$ \\
\hline & Strongly agree & 166 & $57.4 \%$ \\
\hline \multicolumn{4}{|c|}{ Environmental } \\
\hline \multirow[t]{5}{*}{ Pollution } & Strongly disagree & 4 & $1.4 \%$ \\
\hline & Disagree & 20 & $6.9 \%$ \\
\hline & Undecided & 7 & $2.4 \%$ \\
\hline & Agree & 40 & $13.8 \%$ \\
\hline & Strongly agree & 218 & $75.4 \%$ \\
\hline \multirow[t]{6}{*}{ High municipal cost } & Strongly disagree & 7 & $2.4 \%$ \\
\hline & Disagree & 37 & $12.8 \%$ \\
\hline & Undecided & 38 & $13.2 \%$ \\
\hline & Agree & 40 & $13.8 \%$ \\
\hline & Strongly agree & 166 & $57.4 \%$ \\
\hline & Unknown & 1 & $0.4 \%$ \\
\hline \multirow[t]{6}{*}{ Violating water restrictions } & Strongly disagree & 35 & $12.1 \%$ \\
\hline & Disagree & 11 & $3.8 \%$ \\
\hline & Undecided & 37 & $12.8 \%$ \\
\hline & Agree & 33 & $11.4 \%$ \\
\hline & Strongly agree & 172 & $59.5 \%$ \\
\hline & Unknown & 1 & $0.4 \%$ \\
\hline \multicolumn{4}{|c|}{ Economic } \\
\hline \multirow[t]{5}{*}{ Unexpected increase in financial cost } & Strongly disagree & 84 & $29.1 \%$ \\
\hline & Disagree & 100 & $34.6 \%$ \\
\hline & Undecided & 30 & $10.4 \%$ \\
\hline & Agree & 51 & $17.6 \%$ \\
\hline & Strongly agree & 24 & $8.3 \%$ \\
\hline \multirow[t]{5}{*}{ Decrease in sales and profit volumes } & Strongly disagree & 23 & $8.0 \%$ \\
\hline & Disagree & 20 & $6.9 \%$ \\
\hline & Undecided & 19 & $6.6 \%$ \\
\hline & Agree & 42 & $14.5 \%$ \\
\hline & Strongly agree & 185 & $64.0 \%$ \\
\hline
\end{tabular}

Source: authors 


\section{ENTREPRENEURSHIP AND SUSTAINABILITY ISSUES}

ISSN 2345-0282 (online) http://jssidoi.org/jesi/

2020 Volume 7 Number 4 (June)

http://doi.org/10.9770/jesi.2020.7.4(49)

Table 10 shows that the components of sustainability, namely; social, environmental and economic factors pose quite a number of risks to FMCG SMEs. However, further analysis indicates that the environmental component of sustainability poses the largest risk on the sustainability of FMCG SMEs. More specifically, aspects such as pollution (75.4\% of the respondents strongly agree), high municipal cost (57.6\% of the respondents strongly agree), and violation of water restrictions (59.7\% of the respondents strongly agree).

The social component of sustainability poses the second largest risk on the sustainability of FMCG SMEs and more specifically relating to the loss of customers ( $74.0 \%$ of the respondents strongly agree) and loss of key suppliers (57.4\% of the respondents strongly agree). Lastly, the economic component of sustainability poses the third largest risk on the sustainability of FMCG SME's as a result of decreases in sales and profit volumes (64.0\% of the respondents strongly agree).

The foregoing survey questionnaire results suggest that the risks posed to FMCG SMEs by the components of sustainability are multiple. The risk experts interviewed concurred with the foregoing results, as noted in the following sentiments shared:

"All the areas you have mentioned pose many risks to every business, for example, the environmental part may cause the business to experience higher costs for energy, water and other resources, extreme water restrictions due to climate changes may also affect businesses. Then for the economic part, circumstances like inflation and the general government regulations may result in a significant loss for any business. Lastly, for the social part, if the business doesn't properly manage the actions that affect the community around it including customers, it is likely to be faced with public outcry and damage to reputation". (Participant - BRE1).

“A retail SME's economic, environmental and social performance is likely to have financial impacts, legal impacts and reputational impacts. It is important that these factors are understood and considered when preparing a risk management plan and in subsequent risk assessment activities, in order to minimise and manage the risks caused by them" (Participant - BRE2).

\section{Conclusion, implications and scope for future research}

Drawing on the literature and findings, one could conclude that FMCG SMEs face multiple risks that have been traditionally classified into financial, strategic, operational and compliance risks. Beyond this, the vulnerability of the FMCG SMEs to risks from sources that can be classified under the sustainability factor was eminent. While the latter outcome reiterates the critical importance for risk assessment, the clarion call is for FMCG SMEs to adopt a holistic approach to the assessment and management of the sources of risks to the firm.

\subsection{Theoretical implications}

This paper contributes to the existing body of knowledge regarding sustainability and risk management in view of evolving risk sources by providing a holistic risk assessment framework for FMCG SMEs (See Figure 1). 


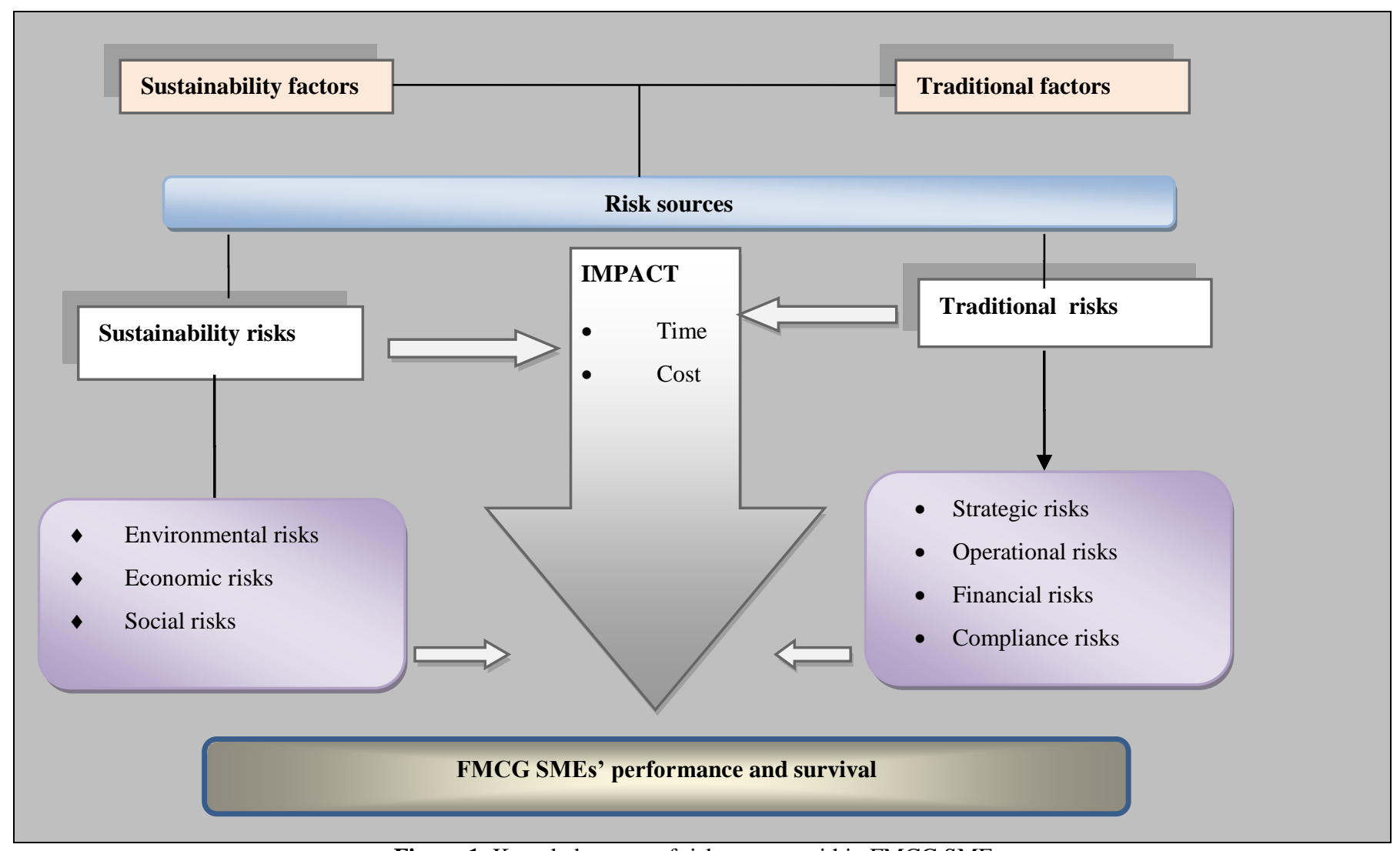

Figure 1. Knowledge map of risk sources within FMCG SMEs Source: authors

From the literature review and results analysed, it was obvious that two broad categories of risks that may inhibit FMCG SMEs from attaining their objectives:

Firstly, sustainability risks that emanate from environmental, social and economic factors. The key drivers of environmental risks in FMCG SMEs are food packaging, water consumption, and energy efficiency. Then for the social part, the key drivers are human rights violations within the workforce, poor supplier relationships, poor customer service and labour issues. Businesses that have problems with social risk face negative publicity, and a damaged legal standing, and may not be sustainable in the long run. For the economic risks, the key drivers fluctuating interest rates and inflation.

Secondly, the traditional risks associated with normal business operations. As such, the key drivers for traditional risks include weak internal controls, failures in the systems, poor governance, ambiguous business objectives and poor credit policy. Note should be taken that the reporting risks were not included in the knowledge map since the survey results did not show any indication that FMCG SMEs are faced with reporting risks.

\subsection{Managerial implications}

From a managerial perspective, this paper hopes to broaden the understanding of the potential risks that FMCG SMEs are exposed to using the sustainability lens. In so doing this paper draws the manager's attention to emerging risk areas that might otherwise be missed by existing risk management tools. In practice, this paper suggests that the environmental aspect of sustainability may cause the business to experience higher costs for energy and water, and face extreme water restrictions due to climate changes. In the same token, economic 


\section{ENTREPRENEURSHIP AND SUSTAINABILITY ISSUES}

ISSN 2345-0282 (online) http://jssidoi.org/jesi/

2020 Volume 7 Number 4 (June)

http://doi.org/10.9770/jesi.2020.7.4(49)

circumstances like inflation may pose significant loss for any business due to increase in input costs like electricity. Lastly, for the social aspect, if the business does not properly manage its actions that affect key stakeholders such as customers, suppliers and the community around, it is likely to be faced with negative publicity.

Concuring with, Singh, et al., (2020) one may advance that risk managers should capture sustainability factors into their risk management process. By so doing, sustainability issues will be dealt with at the risk mitigation stage. Ultimately, the management will achieve cost reduction while also contributing to the SDGs through reduced energy consumption, improving hygiene, sustainable packaging, and effective water risk management and stewardship.

\subsection{Area for further research}

In this study, it emerged that FMCG SMEs face an array of risks in their operations. These risks are related to compliance, financial, social, environmental, operational, economic and strategic factors. However, there is currently no holistic risk management model, specifically addressing SME social and environmental factors. The traditional risk management approaches including Enterprise Risk Management are inherently internally focused as they only look at operational, economic and strategic factors. On this basis lay the need to develop a holistic risk management model in future, to address all the key risk areas in FMCG SMEs. The model should capture social and environmental factors into the risk assessment of FMCG SMEs, thus, looking beyond financial, compliance, strategic and operational factors.

\section{References:}

Allan, N. \& Beer, L. e2006. Strategic risk: It's all in your head. University of Bath; School of Management Working Paper Series 2006.01. Association of Chartered Certified Accountants. 2015. Strategic and operational risks. Available from: http://www.accaglobal.com/ie/en/student/exam-support-resources/professio nal-exams-study-resources/p1/technical-articles/strategicoperationalrisks.html

Aureli, S. \& Salvatori, F. 2013. The current state of risk management in Italian small and medium-sized enterprises. Proceedings of the 8th International Conference Accounting and Management Information Systems AMIS 2013.

Ayandibu, A.O. \& Houghton, J. 2017. The role of small and medium scale enterprise in local economic development (LED). Journal of Business and Retail Management Research, 11(2), 133-139.

Banerjee, S., Dasgupta, S. \& Kim, Y. 2008. Buyer-supplier relationships and the stakeholder theory of capital structure. The Journal of Finance, 63, 2507-2552.

Basel Committee on Banking Supervision. 2011. Principles for the sound management of operational risk. Available from: http://www.bis.org/publ/bcbs195.pdf

Basel Committee on Banking Supervision. 2001. Operational risk. Available from: https://www.bis.org/publ/bcbsca07.pdf

Bure, M. \& Tengeh, R.K. 2019. Implementation of internal controls and the sustainability of SMEs in Harare in Zimbabwe. Entrepreneurship and Sustainability Issues, 7(1), 201-218. http://doi.org/10.9770/jesi.2019.7.1(16)

Brockett, A.M. \& Rezaee, Z. 2012. Corporate sustainability: integrating performance and reporting. Hoboken, NJ: John Wiley.

Calton, J. 2001. Dialogue and the art of thinking together. A pioneering approach to communicating in business and in life by William Isaacs, Business and Society, 40(3), 343-348. 


\section{ENTREPRENEURSHIP AND SUSTAINABILITY ISSUES}

ISSN 2345-0282 (online) http://jssidoi.org/jesi/

2020 Volume 7 Number 4 (June)

http://doi.org/10.9770/jesi.2020.7.4(49)

Center for Audit Quality. 2012. Guide to internal control over financial reporting. Washington, DC: CAQ.

CGAP. 2009. Operational risk management for microfinance entities. Available from: http://www.microfinancegateway.org/gm/document1.9.34371/CGAP\%20Operational\%20Risk\%20Management\%20Course.pdf

Chehabeddine, M., Tvaronavičienė, M. 2020. Securing regional development. Insights into Regional Development, 2(1), 430-442. http://doi.org/10.9770/IRD.2020.2.1(3)

Coles, R. \& Kirwan, M. 2011. Food and Beverage packaging technology. Chichester: Wiley-Blackwell.

COSO. 2004. Enterprise Risk Management - Integrated Framework. Executive Summary. Available from: http://www.coso.org/documents/coso_erm_executivesummary.pdf

Coyle, B. 2004. Risk Awareness and Corporate Governance. Canterbury: Global Professional Publishing Kent.

Daniel, L. 2019. Eskom to increase electricity tariffs by $80 \%$ to recoup financial losses. Available from: https://www.thesouthafrican.com/news/eskom-to-increase-electricity-prices-in-2020/

Deloitte. 2013. Exploring strategic risk. Available from: https://www2.deloitte.com/content/dam/Deloitte/global/Documents/GovernanceRisk-Compliance/dttl-grc-exploring-strategic-risk.pdf

Dietsche, C. 2009. Networking against stakeholder risks: A case study on SMEs in International Shrimp Trade, Belgeo, 10(1), 27-42.

EMF. 2012. Towards the circular economy Vol. 1. In Economic and business rationale for an accelerated transition. Ellen MacArthur Foundation. Available from:

https://www.ellenmacarthurfoundation.org/assets/downloads/publications/Ellen-MacArthur-Foundation-Towards-the-Circular-Econom y-vol.1.pdf

EPA. 2013. Municipal Solid Waste Generation, Recycling, and Disposal in the United States: Facts and Figures for 2013. Available from: https://archive.epa.gov/epawaste/nonhaz/municipal /web/pdf/msw2013rpt.pdf

Enow, S.T., Kamala, P. 2016. The accounts payable management practices of small, medium and micro-enterprises in the Cape Metropolis, South Africa. Innovations, 13, 77-83.

Forum for the Future. 2014. Scaling disruptive innovation in sustainable packaging. Available from: http://www.forumforthefuture.org/sites/default/files/Sustainable\%20packaging.pdf

Godbole, P. 2012. Effective risk management is crucial for small businesses: Mritunjay Kapur. Business Standard, January 17. Available from: $\quad$ http://www.business-standard.com/article/sme/effective-risk-management-is-crucial-for-small-businesses-mritunjay-kapur $\underline{1120117001021}$

Goldberg, M. \& Palladini, E. 2010. Managing risk and creating value with microfinance. Washington D.C: World Bank Publications.

Green Restaurant Association. 2005. Energy and Water. Available from: http://dinegreen.weebly.com/energywater.html.

Horcher, K.A. 2011. Essentials of Financial Risk Management. Hoboken: John Wiley \& Sons.

Hubner, A., Kuhn, H. \& Sternbeck, M. 2013. Demand and supply chain planning in grocery retail: An operations planning framework. International Journal of Retail \& Distribution Management, 41(7), 512-553.

Hussain, I., Farooq Z. \& Akhtar W. 2012. SMEs development and failure avoidance in developing countries through public-private partnership. African Journal of Business Management, 6(4), 1581-1589.

Ikediashi, D., O. Ogunlana, S. \& O. Ujene, A. 2014. An investigation on policy direction and drivers for sustainable facilities management practice in Nigeria. Journal of Facilities Management, 12(3), 303-322.

Irwin, R \& Kennedy, A. 2017. Sustainability and enterprise risk management: The first step towards integration. Geneva: World Business Council for Sustainable Development. 


\section{ENTREPRENEURSHIP AND SUSTAINABILITY ISSUES}

ISSN 2345-0282 (online) http://jssidoi.org/jesi/

2020 Volume 7 Number 4 (June)

http://doi.org/10.9770/jesi.2020.7.4(49)

Ismail, N., Othman, A.A., Yousop, N.M. \& Ahmad, Z. 2016. Empirical Evidence on the SMEs Risks Framework in Malaysia. Journal of Advanced Research in Social and Behavioural Sciences, 3(1), 52-62.

Johnson \& Johnson. 2013. Framework for enterprise risk management. Available from: https://www.jnj.com/sites/default/files/pdf/JnJ_RiskMgmt_ERMFramework_guide_v16a.pdf

Kaplan, R.S. \& Mikes, A. 2012. Managing risks: A new framework. Harvard Business Review, 90(6).

Koor, F. 2018. Sustainability trends shaping retail in 2018. Available from:

https://www.bizcommunity.com/PDF/PDF.aspx?1=196\&c=457\&ct=1\&ci=176254

KPMG. 2014. Fast moving consumer goods in Africa. Available from: http://kpmg.com/Africa

Kumar, D. 2002. CPG Industry: Supply chain drivers using SCOR. Vision: The Journal of Business Perspective; Special Issue on Supply Chain Management, 7(1), 99-107.

Kumar, D. 2004. Beyond the low-hanging fruit: using lean concepts to peel away the supply chain inefficiencies. Industrial Engineer, 36(5):44-48.

Mohammed, A. \& Sykes, R. 2012. Sharpening strategic risk management. Available from: http://www.pwc.com/gx/en/services/advisory/consulting/risk/resilience/publications/sharpening-strategic-risk-management.html [Accessed 15/10/2018].

Nyakang'o, E.O. \& Kalio, A.M., 2013. Effect of financial risks on performance of small and medium enterprises in the hotel industry in Nakuru Municipality, Kenya. International Journal of Innovative Research and Development, 2(11), 257-263.

Ogbor, J.O. 2009. Entrepreneurship in Sub-Saharan Africa: A strategic management perspective. Bloomington: Author House.

Pradana, M. \& Bandula, J. 2012. Risk management practices in small and medium enterprises: evidence from Sri Lanka, International Journal of Multidisciplinary Research, (2)7, 226-234.

Risk Management Association. 2017. Operational risk management. Available from: http://www.rmahq.org/operational-risk/ SABCOHA. 2014. Western Cape Business Sector Provincial Strategic Plan 2011-2015. Available from: http://www.sabcoha.org/reports/

Sales, F. 2014. Compliance risk. Available from: http://searchcompliance.tech target.com/ definition/compliance-risk

Statistics South Africa. 2019. Consumer Price Index. Available from: http://www.statssa.gov.za/publications/P0141/P0141August2019.pdf

SBP Alert, 2013. Developing a new path for SMEs in South Africa; Reassessing for Growth. SPB Occasional Paper, 1.

Schlierer, H.J., Werner, A., Signori, S., Garriga, E., Von Weltzien Hoivik, H., Van Rossem, A. \& Fassin, Y. 2012. How do European SME owner-managers make sense of stakeholder management: Insights from a cross-national study. Journal of Business Ethics, 109(1), 39-51.

Sheehan, M.J. 2013. Sustainability and the small and medium enterprise (SME): Becoming more professional. Australia: Xlibris Corporation.

Singh, J. 2014. FMCG (Fast Moving Consumer Goods) An Overview. International Journal of Enhanced Research in Management \& Computer Applications, 3(6), 14-16.

Singh, M.P., Chakraborty, A., Roy, M. \& Tripathi, A. 2020. Developing SME sustainability disclosure index for Bombay Stock Exchange (BSE) listed manufacturing SMEs in India. Environment, Development and Sustainability. https://doi.org/10.1007/s10668-019-00586$\underline{\mathrm{Z}}$

Stahel, W.R. \& Clift, R. 2015. Stocks and flows in the performance economy. In R. Clift \& A. Druckman (Eds.), Taking Stock of Industrial Ecology (pp. 137-158). Cham: Springer International Publishing.

Surridge, M \& Gillespie, A. 2017. AQA GCSE (9-1) Business. London: Hodder Eduaction. 


\section{ENTREPRENEURSHIP AND SUSTAINABILITY ISSUES}

ISSN 2345-0282 (online) http://jssidoi.org/jesi/

2020 Volume 7 Number 4 (June)

http://doi.org/10.9770/jesi.2020.7.4(49)

Tampa Water Department. 2010. Restaurant water efficiency checklist. Available from: http://www.tampagov.net/dept Water/information resources/Efficiency checklists/restaurant water efficiency checklist.asp

Taylor, J.C. 2012. Concepts of strategic risks and managing strategic risks. Available from: http://vsu.edu/files/docs/internal-audit/riskconcepts.pdf

Tonello, M. 2012. Strategic risk management: a primer for directors. Available from: https://corpgov.law.harvard.edu/2012/08/23/strategic-risk-management-a-primer-for-directors/

UNESCO. 2010. Risk Management Handbook. Available from: http://unesdoc.unesco.org/images/0019/001906/190604e.pdf

Vaishnani, H.B. 2011. Effects of sales promotions on consumer preferences and brand equity perception, thesis submitted in partial fulfillment of the requirements for the Degree of Doctor of Philosophy to Saurashtra University.

Van Eeden, S., Viviers, S. \& Venter, D. 2004. An exploratory study of selected problems encountered by small businesses in a South African context. Journal of African business, 5(1):45-72.

Viviers, W. 2004. Competitive advantage: intelligence - what intelligence? Finance Week, 1.

Von Rossing, R. 2007. IT control objectives for Basel II: the importance of governance and risk management for compliance. Rolling Meadows, IL: IT Governance Institute.

Watt, J. 2007. Strategic risk management for small businesses, in Reuvid, J. (Ed.): Managing business risk - A practical guide to protecting your business, London: Kogan Page.

WEF Global Risks Report. 2019. The Global Risks Report 2019, 14th Edition. Geneva: World Economic Forum.

WEF Global Risks Report. 2016. The Global Risks Report 2016, 11th Edition. Geneva: World Economic Forum.

Wurzler, J. 2013. Information risks \& risk management. Available from: http://www.sans.org/readingroom/whitepapers/policyissues/information-risks-riskmanagement34210

Yusuf, T. O. \& Dansu, F. S. 2013. SMEs, Business Risks and Sustainability in Nigeria. European Journal of Business and Social Sciences, 2(9):76-94.

Zhao, S. \& Zeng, M. 2014. Theory of SMEs financial risk prevention and control. In 2014 International Conference on Education, Management and Computing Technology (ICEMCT-14). Atlantis Press.

Oscar CHAKABVA

ORCHID ID: https://orcid.org/0000-0002-5357-1363

Robertson K. TENGEH

ORCHID ID: https://orcid.org/0000-0003-2485-0205

Jobo DUBIHLELA

ORCHID ID: https://orcid.org/0000-0001-6228-6524

Copyright (C) 2020 by author(s) and VsI Entrepreneurship and Sustainability Center

This work is licensed under the Creative Commons Attribution International License (CC BY).

http://creativecommons.org/licenses/by/4.0/

(c) (i) Open Access 